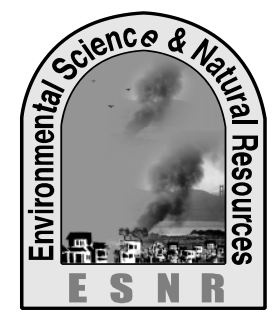

\title{
Assessment of Physicochemical Water Quality Parameters and Heavy Metals Concentration in Water Samples from Buriganga River Adjacent to Dhaka City
}

\author{
M. M. M. Hoque* and P. P. Deb
}

Department of Environmental Science and Resource Management, Mawlana Bhashani Science and Technology University, Tangail-1902

*Corresponding author: huqmbstu@gmail.com

\begin{abstract}
This study was conducted to know the status of physicochemical water quality parameter and heavy metal concentration in the water of Buriganga river, adjoining to Dhaka city. Water samples were collected from five different points of Buriganga river and were analyzed to determine $\mathrm{pH}$, electrical conductivity (EC), total dissolved solids (TDS), dissolved oxygen (DO), biological oxygen demand $(\mathrm{BOD})$, chromium $(\mathrm{Cr})$, lead $(\mathrm{Pb})$, cadmium $(\mathrm{Cd})$, copper $(\mathrm{Cu})$ and manganese $(\mathrm{Mn})$ content. Most of the measured water quality parameters and concentration of heavy metals were exceeded the standard level set by ECR and ADB. Among heavy metals concentration, level of chromium and cadmium were 4-5 times higher than the standard drinking level, these results indicate that surrounding industrial wastewater discharging from textile and tannery industries, which pollute the Buriganga river water. During the observation, at Hazaribagh station BOD level was found 32 times higher than drinking water standard level and 6 times higher than standard irrigation level, indicating Buriganga river water is extremely polluted by microorganism and is not suitable for household and irrigational use. Similarly, DO level at Buriganga river water was 5 times lower than the standard level, which indicates that Buriganga river water is extremely polluted and is unsuitable for aquatic life which are dependent on DO for their sustain. In the present study, the measured level of EC, chromium, cadmium and copper were found higher level as compare to the previous studies.
\end{abstract}

Key words: BOD, Buriganga, DO, Heavy metal, Water pollution and Water quality

\section{Introduction}

Buriganga is one of the largest rivers in Bangladesh, which flows through west and south of Dhaka. It is located on the south side of Dhaka city and is significantly polluted by the addition of industrial effluents, urban sewage and solid waste due to human activities in these areas (Ahmed, 2005). At present Buriganga is one of the most polluted rivers in Bangladesh. Dhaka is considered as one of the ten 'Mega Cities' of the world, where only a small fraction of the total wastewater is treated and the amount of untreated wastes, both from domestic and industrial source, being released into the Buriganga (Kamal et al., 1999).

The river Buriganga flowing through the heart of the Dhaka city, carry heavy loads of industrial wastes. These industrial wastes, which are discharged in to the river especially effluents from tanneries located in Hazaribagh area. The Department of Environment (DoE) identified 249 factories along the river Buriganga (Sarker, 2005). Most of the industries and factories of Dhaka are situated on the banks of the Buriganga or very close to the river system. The industries mainly textiles and garments-cum dying factories, which mushroomed in this area without setting up waste treatment facilities during the past decade. Moreover, urban sewage of the Dhaka city are also thrown in the Buriganga, as a result, huge amount of effluents and solid wastes are adding to the river water as well as to the sediments. Through this way, the river Buriganga is apprehended to be one of the polluted river systems of Bangladesh (Sarker, 2005).

Surface water is the most important resource throughout the world. Country likes Bangladesh, where a majority of it's population depends on surface water directly or indirectly. River water is highly susceptible to contamination from various sources of pollutants.
Different chemicals and trace metals have been such a pervasive surface water problem, affecting both moving water and still water, which need to be given special attention. River basins generally constitute areas with a high population density owing to favorable living conditions such as the availability of fertile lands, water for irrigation, industrial and drinking purposes and efficient means of transportation (Vega et al., 1998).

The worldwide systematic monitoring of environmental pollution by heavy metals began since the 1960s. Pollution of the natural environment by heavy metals is a worldwide problem because these metals are indestructible and most of them have toxic effects on living organisms, when they exceed a certain concentration (Nuremberg, 1984). Heavy metals are one of the serious pollutants in natural environment due to their toxicity, persistence and bioaccumulation problems (Nouri et al., 2008).

Heavy metals contamination in river is one of the major quality issues in many fast growing cities, because maintenance of water quality and sanitation infrastructure did not increased along with population and urbanization growth especially for the developing countries (Ahmad et al., 2010). Trace metals enter in river from variety of sources; it can be either natural or anthropogenic (Bem et al., 2003). Anthropogenic sources of heavy metal contamination includes mining, disposal of untreated and partially treated effluents contain toxic metals, as well as metal chelates from different industries and indiscriminate use of heavy metal-containing fertilizer and pesticides in agricultural fields (Hatje et al., 1998). Heavy metals are nonbiodegradable in nature and can accumulate in the human body system, causing damage to nervous system and internal organs (Lee et al., 2007). However, the rivers play a major role in assimilation or transporting municipal and industrial waste water and run-off from agricultural and mining land (Singh et al., 2005). 
Tanneries of Hazaribagh area discharge some 21,600 square meters of liquid wastes everyday into the Buriganga (Kamal et al., 1999).These harmful effluents, contains chromium, lead, sulphur, ammonium, salt and other materials, are severely polluting the Buriganga River (Faisal et al., 2001).

There are 627 dyeing industries are situated beside the Buriganga River near Jingira, Karanigang areas (Kamal et al., 1999). Discharges from these industries, 5000 square meters of effluents are released daily into the Buriganga. These effluents comprise some toxic chemicals such as epoxy, polyurethane, enamel, ductilesilvery white metal, hydrochloric acid, alkalis, lime, caustic soda, aluminum, zinc chromate, zinc phosphate, asbestos etc. (Rahman and Bakri, 2010).

The industrial pollutant has a great impact on water quality and pollutes the water at a large extent. Heavy metals such as $\mathrm{Cr}, \mathrm{Cu}, \mathrm{Co}, \mathrm{Zn}, \mathrm{Ni}, \mathrm{Mn}$ and many other metals passing from industrial waste into water and soil, attain higher concentrations and accumulate in dangerous quantities in different body parts of plant and finally exerts serious health hazards to human beings and domestic animals through bio-magnifications (Ray, 1994).

Chemicals found in industrial effluents are not only poisonous to human beings and but also found toxic to aquatic life (WHO, 2002).Contaminated water directly affects the health of inhabitants, fish resources, flora and fauna. Pollution and contamination of the river water has impacts on the aquatic resources. The main objectives of the current study is to determine the physico-chemical water quality parameters and concentration of heavy metals of water samples from the Buriganga river and to compare the current results with the standard level and also with the previous study that was conducted in different locations of the Buriganga river.

\section{Methodology of the study}

\section{Water sampling}

The study was conducted in five different locationslocation of Buriganga including 1. Gabtoli, 2. Dipnagar, 3. Dhaka uddan, 4. Mohammadpur and 5. Hazaribagh from May-June, 2016. Fig. 1 shows the study area and sampling points.We collected 10 (ten) water samples from five different locations of the Buriganga river were using $500 \mathrm{ml}$ plastic bottles to determine the level of $\mathrm{pH}, \mathrm{EC}$, TDS, BOD, chromium, lead, cadmium, copper and manganese. To avoid contamination the bottles were rinsed with $\mathrm{H}_{2} \mathrm{SO}_{4}$ and dried well before sampling. The samples were stored in a cool dark place until analysis.

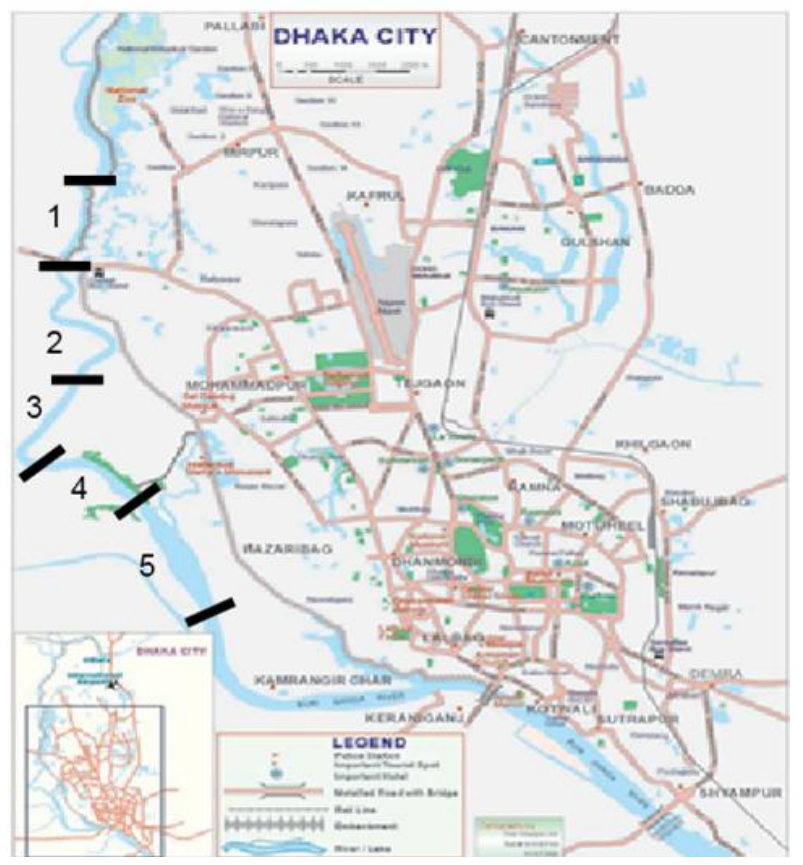

Fig. 1. Sampling stations of the study. The numbers and thick black marks in the map represent sample identification numbers and sample location, respectively.

\section{Physico-chemical water quality parameters}

pH

$\mathrm{pH}$ is an important water quality parameter. The $\mathrm{pH}$ scale is usually represented as ranging from $0-14$. In this study we measured $\mathrm{pH}$ by a digital $\mathrm{pH}$ meter (model: Adwa-AD1000).

\section{Electrical conductivity (EC)}

Electrical conductivity (EC) was measured by a digital EC meter (model: HM Digital)

\section{Dissolved oxygen (DO)}

The analysis of DO is a key test in water pollution control activities. In this study, DO was measured with a digital DO meter (model: Lutron-DO-5509).

\section{Biochemical Oxygen Demand (BOD)}

Biochemical Oxygen Demand (BOD) is the measuring of the presence of degradable organic material in a water sample. The amount of oxygen required by the microorganisms stabilizes the biologically degradable organic matter under aerobic conditions. The principle of the method involves, measuring the difference of the oxygen concentration between the samples and incubating it for 5 days at $20^{\circ} \mathrm{C}$.

The BOD is calculated by$\mathrm{BOD},\left(\mathrm{mg} \mathrm{l}^{-1}\right)=\mathrm{D}_{\mathrm{o}}-\mathrm{D}_{5} \times$ dilution factor

Where

$\mathrm{D}_{\mathrm{o}}=$ Initial DO of the sample

$\mathrm{D}_{5}=\mathrm{DO}$ after 5 days

\section{Water sample analysis for Heavy metals}

Determination of heavy metal concentrations including Chromium (Cr), Copper (Cu), Manganese (Mn), Lead $(\mathrm{Pb})$ and Cadmium $(\mathrm{Cd})$ in water samples was done by 
using an Atomic Absorption Spectrophotometer (AAS). Mono element hollow cathode lamp was employed for the determination of each heavy metal of interest. A standard line was prepared by plotting the absorbance reading on $\mathrm{Y}$-axis versus the concentration of each standard solution of metal on $\mathrm{X}$-axis. Then, the concentration of metal was calculated in the water samples of interest by plotting the AAS reading on the standard line.

\section{Results and discussion}

\section{Physico-chemical water quality parameters}

Table 1. Level of physico-chemical water quality parameters from Buriganga and comparison with previous study

\begin{tabular}{|l|l|l|l|l|l|l|}
\hline Parameters & Unit & Min. & Max. & Average & Median & Previous study \\
\hline $\mathrm{P}^{\mathrm{H}}$ & -- & 6.24 & 7.63 & 6.98 & 7.15 & $7.09^{*}$ \\
\hline EC & $\mu \mathrm{s} \mathrm{cm}^{-1}$ & 604 & 1101 & 829 & 818 & $731^{*}$ \\
\hline TDS & $\mathrm{mg} \mathrm{l}^{-1}$ & 112 & 587 & 427 & 489 & $555^{*}$ \\
\hline DO & $\mathrm{mg} \mathrm{l}^{-1}$ & 0.62 & 2.74 & 1.40 & 1.20 & $1.1^{*}$ \\
\hline BOD & $\mathrm{mg} \mathrm{l}^{-1}$ & 21.40 & 63.20 & 45.60 & 48.70 & $82.3^{*}$ \\
\hline
\end{tabular}

*Ahammed et al., 2016
The Fig. 2 is shows the comparison of the observed values of $\mathrm{pH}$ of the sampling stations of Buriganga river with the standard values. Here the highest value of $\mathrm{pH}$ is 7.63 of water observed in sampling station 1 and the lowest is 6.24 was observed in sampling station 3 . According to ECR, 1997 the standard level of $\mathrm{pH}$ for drinking, fisheries and irrigation is ranged for 6.5-8.5.

\section{pH}

$\mathrm{pH}$ is the measure of acidity and alkalinity of a water body. The $\mathrm{pH}$ scale is usually represented as ranging from 0 to 14 , and a value of $\mathrm{pH} 7$ at $25^{\circ} \mathrm{C}$ representing absolute neutrality (Ramesh and Anbu, 1996). The $\mathrm{pH}$ of an aqueous system is a measure of the acid-base equilibrium. It is indicative of the alkalinity $(\mathrm{pH}>7)$ and acidity $(\mathrm{pH}<7)$. In the present study $\mathrm{pH}$ values ranged from 6.24-7.63 (av. 7) these values are similar with the previous study that was conducted in Buriganga Table 1. (Ahammed et al., 2016).
•ECR higher standard

$\Delta$ ECR lower standard

Observed values

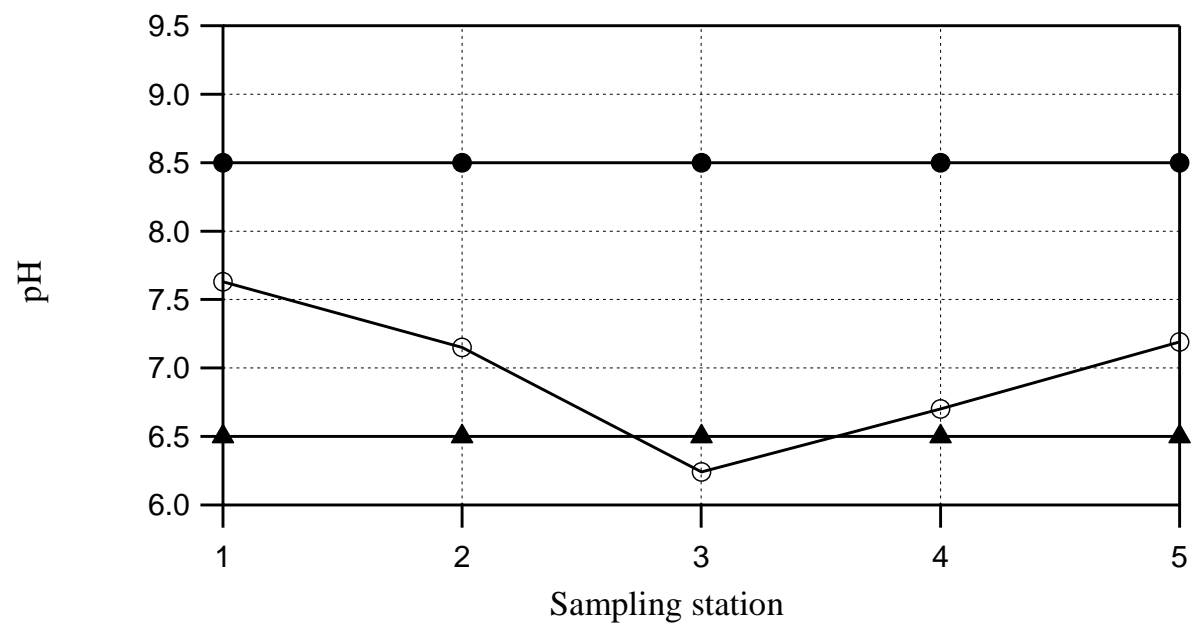

Fig. 2. Comparison of the observed $\mathrm{pH}$ values of the study area with the standard values.

\section{Electrical Conductivity $(\mathrm{EC})$}

Conductivity is a measure of the ability of an aqueous solution to carry an electric current. This ability depends on the presence ion, on their total concentration, mobility and valence and on the temperature of measurement. The values of electrical conductivity ranged from $604-1101 \mu \mathrm{scm}^{-1}$ (av. 829 $\left.\mu \mathrm{scm}^{-1}\right)$. According to ADB 1994, standard level of EC for fishing and irrigation are 1000 and 750 ,
As shown in Fig. 2 observed $\mathrm{pH}$ values of water samples were within the standard level (ECR, 1997) except the sampling point 3 , where experimental value was lower than the ECR lower standard. This result indicates that water body at point 3 may pollute with highly acidic industrial discharge. respectively. Fig. 3 shows the comparison of the observed values of EC with the standard values. Here the highest value of EC is 1101 of water observed in sampling station 5 and the lowest is 604 was observed in sampling station 3. Most of the observed EC values of water were higher than the standard level for irrigation except point 1 and point 3 , which indicating the presence of ionic compounds in water as well as higher concentration of inorganic pollutants from tannery and textile industries. 
-ADB standard for fishing

$\triangle \mathrm{ADB}$ standard for irrigation

Observed values

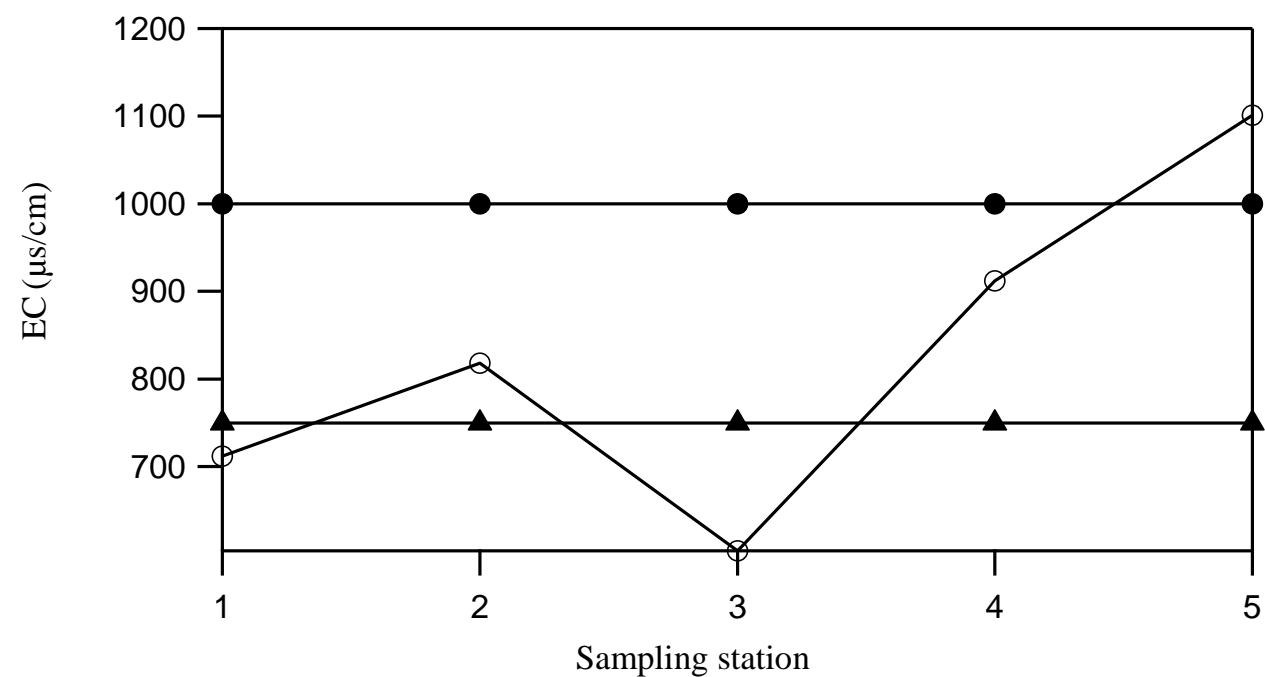

Fig. 3. Comparison of the observed EC values of the study area with the standard values.

\section{Total dissolved solid (TDS)}

Total dissolved solid (TDS) is the measure of total amount of mobile charged ions, including minerals, salts or metals dissolved in a given volume of water, expressed in units of $\mathrm{mg}$ per unit volume of water $\left(\mathrm{mg} \mathrm{l}^{-}\right.$ ${ }^{1}$ ), also referred to as parts per million (ppm). TDS is directly related to the purity of water and the quality of water purification systems. Standard level of TDS for drinking and irrigation are 1000 and 2000, respectively
(ADB, 1994). Fig. 4, shows a comparison of TDS with the observed and the standard values (drinking and irrigation). Highest value of TDS $587\left(\mathrm{mg} \mathrm{l}^{-1}\right)$ was observed in sampling station 5 and the lowest was 112 $\left(\mathrm{mgl}^{-1}\right)$ was observed in sampling station 1. All of the observed TDS values of water were within the standard level for drinking and irrigation. These results indicate that the amount of dissolve solid particles in surface water is not so high.

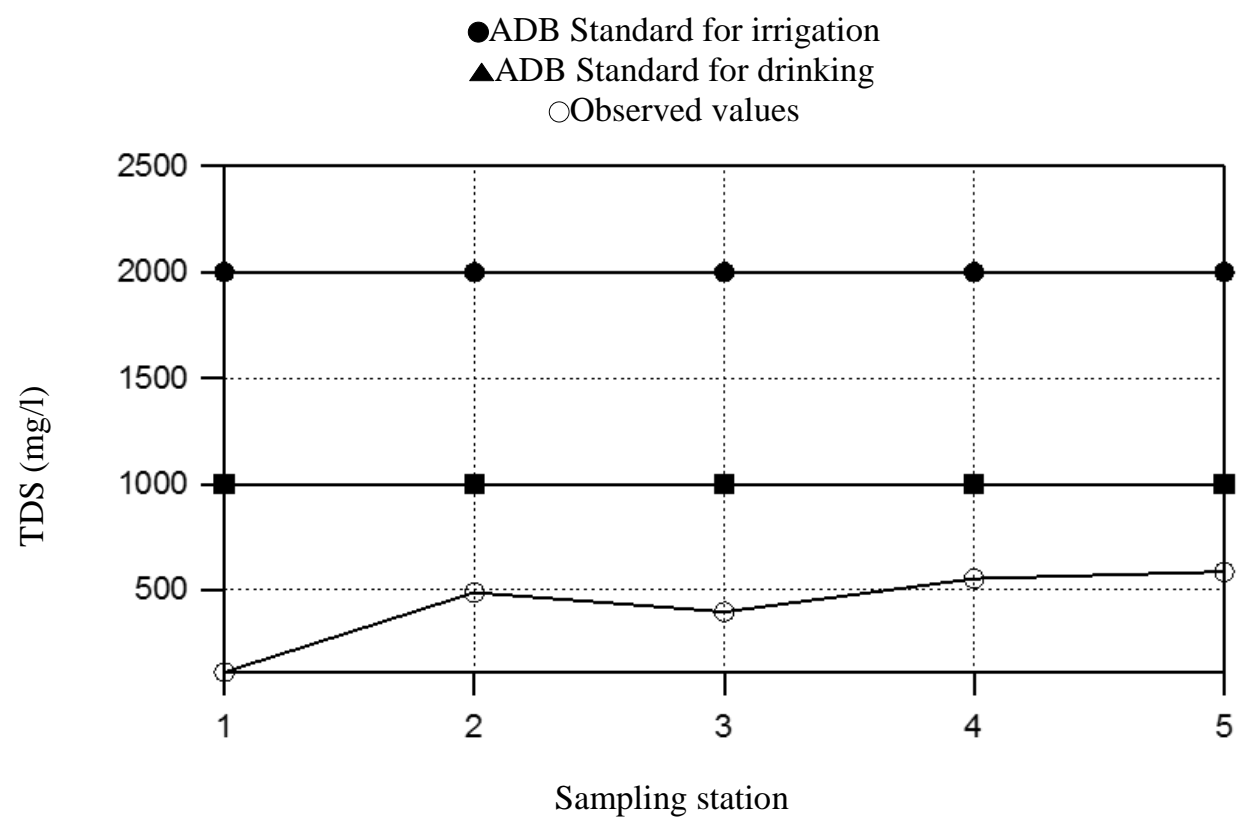

Fig. 4. Comparison of the observed values of TDS of the study area with the standard values

\section{Dissolved oxygen (DO)}

DO is the amount of oxygen that is present in water as dissolved state for aquatic life. DO indicate the organic pollution in water. It is measure of the strength of sewage or polluted water. Fig. 5 shows a comparison of the observed DO of the sampling stations of Buriganga with that of the standard values. Here the highest value of DO is $2.74 \mathrm{mg} \mathrm{l}^{-1}$ of water observed in sampling station 1 and the lowest is $0.62 \mathrm{mg} \mathrm{l}^{-1}$ was observed in sampling station 5. As described in ECR, 1997 standard level of DO for drinking and irrigation are $6 \mathrm{mg} \mathrm{l}^{-1}$ or above and $5 \mathrm{mg} \mathrm{l}^{-1}$ or above, respectively. The observed DO level of water was very lower than the standard level for irrigation and drinking Fig. 4. In Hazaribagh 
(station 5) the DO level was found about 6 times lower than standard drinking level and about 5 times lower than standard irrigation level. Lowest level of DO at Hazaribagh station may indicate that this area is highly polluted with sewage that is discarded from tanneries. On the other hand, hot water discharges from industries (use for engine cooling) that are thrown to the adjacent water body and caused depletion of DO in this location.

-ECR standard for drinking water

$\triangle E C R$ standard for irrigation

Observed values

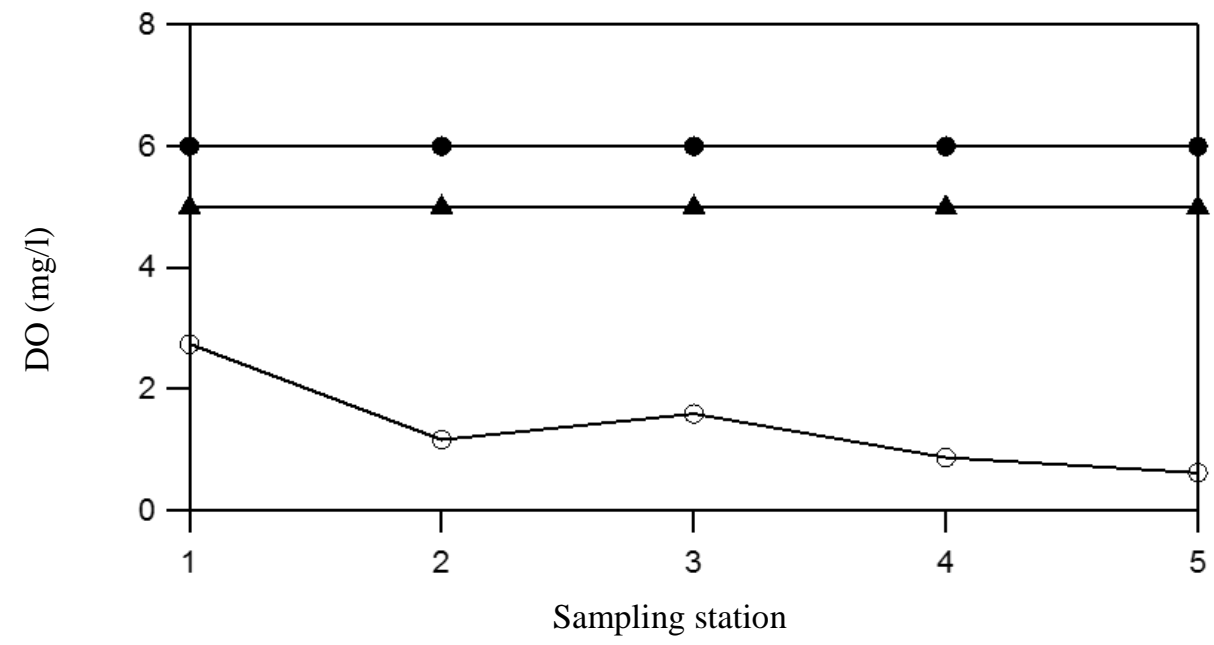

Fig. 5. Comparison of the observed values of DO of the study area with the standard values.

\section{Biochemical oxygen demand $(\mathrm{BOD})$}

The BOD is a measure of the amount of oxygen that bacteria will consume in five days (standard time) at while decomposing organic matter under aerobic conditions. The bio-degradation of organic materials exerts Oxygen tension in the water and increases the biochemical oxygen demand (Abida, 2008). Water having low level of BOD is an indicator of low nutrient levels; therefore, much of the oxygen remains in the water. Standard levels of BOD for drinking and irrigation water are 2 and 10, respectively (ECR, 1997). Fig. 6 shows the comparison of the observed values of BOD of the sampling stations of Buriganga with the standard. During the study, the highest level of BOD (63.18), which was water observed in sampling station 5, and the lowest BOD (21.38) was observed in sampling station 2 . It interesting to note that, all of the observed BOD values from Burigonga water samples were very much higher than those of the standard level for irrigation and drinking. Specially, in Hazaribagh (station 5) the BOD level was found about 32 times higher than standard drinking level and about 6 times higher than standard irrigation level. These findings indicate that Burigonga river water is highly polluted with nutrient discharges from industries as well as household and fecal discharge from nearby slums.

-ECR standard for drinking water

$\Delta E C R$ standard for irrigation

Observed values

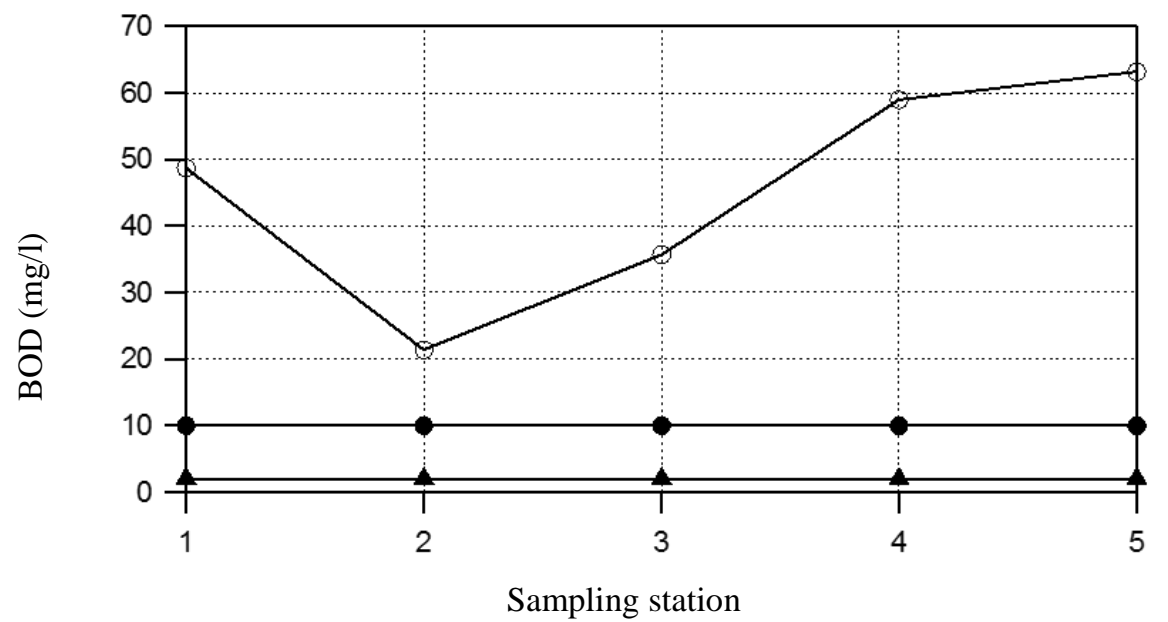

Fig. 6. Comparison of the observed values of BOD of the study area with the standard values. 


\section{Chromium (Cr)}

Chromium is the most abundant element in Earth's crust. Chromium occurs naturally in the environment and is found in rocks, animals, plants, soil and in volcanic dust and gases. Anthropogenic sources of chromium include chrome plating, the manufacture of pigments, leather tanning and treatment of wood products. Also other main sources in the aquatic environment include the waste stream from electroplating and metal finishing industry. As shown in Table 2 concentrations of $\mathrm{Cr}$ varied from $0.06-0.23 \mathrm{mg} \mathrm{l}^{-}$ ${ }^{1}$ (av. $0.13 \mathrm{mgl}^{-1}$ ). Average value of $\mathrm{Cr}$ is $\sim 2$ times higher than the previous study that was conducted for the same river (Rahaman and Bakri, 2010). According to ECR, 1997, standard level of $\mathrm{Cr}$ for drinking is 0.05 $\left(\mathrm{mg} \mathrm{l}^{-1}\right)$. Fig. 6 , shows the comparison of the observed values of $\mathrm{Cr}$ of the sampling stations of Buriganga river with the standard values. Highest value of $\mathrm{Cr}$ was 0.23 $\mathrm{mg} \mathrm{l}^{-1}$ observed in sampling station 5 (Hazaribagh) and the lowest $0.058 \mathrm{mg} \mathrm{l}^{-1}$ was observed in sampling station 2. Measured $\mathrm{Cr}$ values of water samples were higher than the standard level for drinking. In Hazaribagh, the Cr level was found to be 5 times higher than standard drinking level. This finding may indicates that the water sample from the station 5 is highly polluted with $\mathrm{Cr}$ containing compounds, which are added from untreated effluent of nearby tannery industries.

Table 2. Heavy metal concentration in water sample from Buriganga and comparison with previous studies

\begin{tabular}{|c|c|c|c|c|c|c|c|c|}
\hline \multirow{2}{*}{$\begin{array}{l}\text { Heavy metal } \\
\text { concentration } \\
\left(\mathrm{mg} \mathrm{l}^{-1}\right)\end{array}$} & \multicolumn{5}{|c|}{ Sampling station } & \multirow{2}{*}{$\begin{array}{l}\text { Average } \\
\text { value } \\
\left(\mathrm{mg} \mathrm{l}^{-1}\right)\end{array}$} & \multirow{2}{*}{$\begin{array}{l}\text { Standard } \\
(\mathrm{ECR}, \\
1997) \\
\left(\mathrm{mg} \mathrm{l}^{-1}\right)\end{array}$} & \multirow{2}{*}{$\begin{array}{l}\text { Previous } \\
\text { study }\end{array}$} \\
\hline & Station\#1 & Station\#2 & Station\#3 & Station\#4 & Station\#5 & & & \\
\hline $\begin{array}{l}\text { Chromium } \\
\text { (Cr) }\end{array}$ & 0.07 & 0.06 & 0.12 & 0.19 & 0.23 & 0.13 & 0.05 & $0.07^{*}$ \\
\hline $\begin{array}{l}\text { Lead } \\
(\mathrm{Pb})\end{array}$ & 0.002 & 0.004 & 0.003 & 0.003 & 0.002 & 0.003 & 0.05 & $0.003 * *$ \\
\hline $\begin{array}{l}\text { Cadmium } \\
\text { (Cd) }\end{array}$ & 0.020 & 0.011 & 0.014 & 0.010 & 0.017 & 0.014 & 0.005 & $0.013 * *$ \\
\hline $\begin{array}{l}\text { Copper } \\
(\mathrm{Cu})\end{array}$ & 0.014 & 0.09 & 0.023 & 0.017 & 0.012 & 0.031 & 1 & $0.006^{* *}$ \\
\hline $\begin{array}{l}\text { Manganese } \\
\text { (Mn) }\end{array}$ & 0.06 & 0.04 & 0.033 & 0.14 & 0.061 & 0.07 & 0.1 & $0.151 * *$ \\
\hline
\end{tabular}

*=Rahman and Bakri, 2010

**=Mokaddes et al., 2013

\section{Lead $(\mathrm{Pb})$}

Lead is a ubiquitous toxic metal and is detectable in practically all phases of the inert environment and in all biological system. Physical and chemical properties of $\mathrm{Pb}$ are applied in manufacturing, construction and chemical industries. This metal can cause toxic effects in humans and as well as in animals and is also can act as an inhibitory substance for microbiological degradation processes. Lead absorption in children may affect their development and also results in bone stores of lead. In the present observation, concentration of $\mathrm{Pb}$ ranged from 0.002-0.004 $\mathrm{mg} \mathrm{l}^{-1}$ (av. $0.003 \mathrm{mgl}^{-1}$ ). These results are similar to the previous study of $0.003 \mathrm{mg} \mathrm{l}^{-1}$ for the water samples collected from the same river (Mokaddes et al., 2013) (Table 2). Table 2 shows the comparison of the observed values of $\mathrm{Pb}$ of the sampling stations of Buriganga river with the standard values. Highest value of $\mathrm{Pb} 0.0043 \mathrm{mg} \mathrm{l}^{-1}$ was observed in sampling station 2 and the lowest $0.0022 \mathrm{mgl}^{-1}$ was observed in sampling station 1. As mentioned in ECR, 1997, the standard level of $\mathrm{Pb}$ for drinking is $0.05 \mathrm{mg} \mathrm{l}^{-}$ ${ }^{1}$. Observed values of $\mathrm{Pb}$ were within the standard level for drinking (Table 2). It indicates that the Burigonga river water is not highly polluted with $\mathrm{Pb}$ containing compounds.

\section{Cadmium (Cd)}

Cadmium is a non-essential element and it is both bioavailable and toxic. It interferes with metabolic processes in plants and can bio-accumulate in aquatic organisms and finally enters into the food chain. $\mathrm{Cd}$ is bio-persistent and once absorbed by an organism, remains resident for many years although it is eventually excreted. The presence of copper, lead, zinc and cadmium in fish is of serious health concern to human consumers. $\mathrm{Cd}$ concentrations ranged from $0.010-0.020 \mathrm{mg} \mathrm{l}^{-1}$ (av. $0.014 \mathrm{mg} \mathrm{l}^{-1}$ ), which were similar to the previous study of $0.013 \mathrm{mg} \mathrm{l}^{-1}$ from Buriganga water samples (Mokkades et al., 2013). As shown in Table 2, the highest value of Cd was $0.019 \mathrm{mg}$ $\mathrm{l}^{-1}$ observed in sampling station 1 and the lowest $\mathrm{Cd}$ concentration $0.009 \mathrm{mg} \mathrm{l}^{-1}$ was observed in sampling station 4. It is mentionable that the standard level of $\mathrm{Cd}$ for drinking water is $0.005 \mathrm{mg} \mathrm{l}^{-1}$. All of the observed $\mathrm{Cd}$ values for the Buriganga water samples were exceeded the standard level (Table 2). In Gabtoli (Station 1) the $\mathrm{Cd}$ level was found as 4 times higher than standard drinking level. This result indicates that the water sample from station 1 contains higher $\mathrm{Cd}$ containing compounds from nearby industrial effluents as well as from discarded batteries and its fragments from car repairing garage.

\section{Copper $(\mathrm{Cu})$}

Copper is a chalcophilic element which is mostly found in sulfide deposits along with $\mathrm{Pb}, \mathrm{Cd}$ and $\mathrm{Zn}$. It is lustrous, malleable, ductile, soft, tough, corrosion 
resistant and a good conductor of heat and electricity. Copper is widely used in industries. As shown in Table 2 , concentrations of copper ranged from 0.012-0.09 mg $\mathrm{l}^{-1}$ (av. $0.031 \mathrm{mg} \mathrm{l}^{-1}$ ). Highest $\mathrm{Cu}$ concentration $0.09 \mathrm{mg}$ $1^{-1}$ was found in the sampling station 3 and the lowest concentration $0.012 \mathrm{mg}^{-1}$ was observed in sampling station 2. According to ECR, 1997, standard level of $\mathrm{Cu}$ for drinking water is 1 . The observed values of $\mathrm{Cu}$ in all the sampling stations from Buriganga river were within the standard values, which may indicates that the water contains lower amount of $\mathrm{Cu}$ containing compounds during the observation period.

\section{Manganese (Mn)}

Manganese is an essential trace element but is toxic at higher concentrations. $\mathrm{MnO}_{2}$ is the most common mineral of Mn. Manganese is used in dry battery cells, ferro-manganese and other iron alloys, glass, ceramics, electric coils etc. Most of the manganese in the environment is due to burning of fossil fuels. Table 2 shows the observed values of $\mathrm{Mn}$ of the sampling stations of Buriganga river with standard values. Here the highest value of $\mathrm{Mn} 0.142 \mathrm{mg} \mathrm{l}^{-1}$ of water was observed in sampling station 4 and the lowest concentration $0.033 \mathrm{mg} \mathrm{l}^{-1}$ was observed in sampling station 3. Standard level of Mn for potable water is 0.1 $\mathrm{mg} \mathrm{l}^{-1}$. Most of the observed Mn values of water were within the standard level for drinking except station 4 was found as higher than the standard level, which may indicates that the water containing lower amount of $\mathrm{Mn}$ containing compounds.

\section{Conclusions}

Water samples from Buriganga river were collected and analyzed for physicochemical water quality parameters i.e. $\mathrm{pH}, \mathrm{EC}, \mathrm{TDS}, \mathrm{DO}, \mathrm{BOD}$ and heavy metal concentrations like $\mathrm{Cr}, \mathrm{Pb}, \mathrm{Cd}, \mathrm{Cu}$ and $\mathrm{Mn}$ content. Observed values of EC were higher than the standard level for irrigation except point 1 and point 3 , which indicating the presence of ionic compounds in water as well as higher concentration of inorganic pollutants from tannery and textile industries. At the station 5 near to Hazaribagh, concentration of DO was measured as 6 times lower than standard drinking level and 5 times lower than standard irrigation level. Lowest level of DO at Hazaribagh station may indicate that this area is highly polluted with sewage that is discarded from tanneries. All of the observed BOD values from Burigonga water samples were very much higher than those of the standard level for irrigation and drinking. Specially, in Hazaribagh (station 5) the BOD level was found about 32 times higher than standard drinking level and about 6 times higher than standard irrigation level. At Hazaribagh station, Cr level was found to be 5 times higher than standard drinking level. At Gabtoli station (Station 1) Cd level was found as 4 times higher than standard drinking level.

\section{Reference}

Abida, B. and Harikrishna. 2008. Study on the Quality of Water in some streams of Cauvery River. Environmental Journal of Chemistry, 5(2): 377-384.
Ahammed, S.; Tasfina, S.; Rabbani, K. and Khaleque, M. 2016. An Investigation into The Water Quality Of Buriganga -A River Running Through Dhaka, International Journal of Scientific \& Technology Research, 5: 3.

Ahmad, M. K.; Islam, S.; Rahman, S.; Haque, M. R. and Islam, M. M. 2010. Heavy Metals in Water, Sediment and Some Fishes of Buriganga River, Bangladesh, Int. J. Environ. Res., 4(2): 321-332.

Ahmed, R. 2005, Existing Environmental Status of Hazaribagh, Dhaka, Training Institute for Chemical Industries, Narsingdi.

Bem, H.; Gallorini, M.; Rizzio, E. and Krzemin, S. M. 2003, 'Comparative Studies on the Concentrations of Some Elements in the Urban Air Particulate Matter in Lodz City of Poland and in Milan, Italy', Environ. Int., 29(4): 423-428.

Faisal, I. M.; Shamin, R. and Junaid, J. 2001. Industrial Pollution', In: A. Nishat, M. Ullah and A. K. E. Haque (eds.), Bangladesh Environment Outlook2001, Centre for Sustainable Development (CFSD), Dhaka

Hatje, V.; Bidone, E. D. and Maddock, J. L. 1998. 'Estimation of the Natural and Anthropogenic Components of Heavy Metal Fluxes in Fresh Water Sinos River, Rio Grande Do Sul State, South Brazil', Environ. Tech., 19(5): 483-487.

Kamal, M. M.; Malmgren-Hansen, A. and Badruzzaman, A. B. M. 1999. Assessment of pollution of the river Buriganga, Bangladesh, using a water quality model. Water Sci. Technol., 40(2): 129-36.

Lee, C. L.; Li, X. D.; Zhang, G.; Li, J.; Ding, A. J. and Wang, T. 2007. 'Heavy Metals and Pb Isotopic Composition of Aerosols in Urban and Suburban Areas of Hong Kong and Guangzhou, South China Evidence of the Long-Range Transport of Air Contaminants', Environ. Pollut., 41(2): 432-447.

Rahman, M. A. and Dhia, A. B. 2010. A Study on Selected Water Quality Parameters along the River Buriganga, Bangladesh\|, Iranica Journal of Energy \& Environment, 1(2): 81-92.

Meertens, H. C.; Ndege, L. J. and Enserink, H. J. 1995. Dynamics in farming systems: Changes in time and space in Sukumaland, Tanzania, Royal Tropical Institute/Amsterdam Metropolitan City. J. Environ. Sci. \& Natural Resources. 5(2): 349 - 353.

Mokaddes, M. A. A.; Nahar, B. S. and Baten, M. A. 2013. Status of Heavy Metal Contaminations of River Water of Dhaka

Mosley, L.; Sarabjee, S. and Aalbersberg, B. 2004. Water quality monitoring in Pacific Island countries. Handbook for water quality managers \& laboratories, Public Health officers, water engineers and suppliers, Environmental Protection Agencies and all those organizations involved in water quality monitoring (1st Edition). 43 p; ISSN: 1605-4377: SOPAC, The University of the South Pacific. Suva Fiji Islands.

Muwanga, A.; Barifaijo, E. 2006. Impact of industrial activities on heavy metal loading and their physico- 
chemical effects on wetlands of the Lake Victoria basin(Uganda).

Naaz, S. and Pandey, S. N. 2010. Effects of industrial waste water on heavy metal accumulation, growth and biochemical responses of Lettuce (Lactuca sativa L.). J. Environ. Biol., 31: 273-276.

Nabulo, G.; Oryem, O. H.; Nasinyama, G. W. and Cole, D. 2008. Assessment of $\mathrm{Zn}, \mathrm{Cu}, \mathrm{Pb}$ and $\mathrm{Ni}$ contamination in wetland soils and plants in the lake basin. Int. J. Environ. Sci. Techn., 5(1): 65-74.

Nadia, M. A. 2006. Study on effluents from selected sugar mills in Pakistan: Potential environmental, health, and economic consequences of an excessive pollution load: Sustainable Development Policy Institute. Islamabad, Pakistan.

Nouri, J.; Mahvi, A. H.; Jahed, G. R. and Babaei, A. A. 2008. Regional Distribution Pattern of Groundwater Heavy Metals resulting from Agricultural Activities, Environ. Geo., 55(6): 1337-1343.

Nuremberg, H. W. 1984. The voltammetric approach in trace metal chemistry of natural waters and atmospheric precipitation. Anal. Chim. Acta., 164: $1-21$.

Odiete, W. O. 1999. Environmental physiology of animals and pollution. Diversified Resources Limited. pp. 261.

Okafor, N. 1985. Aquatic and waste Microbiology, 1st edition. Enugu: Fourth Dimension Publishing Company Limited. pp. 1-14.

Pitlik, S.; Berger, S. A. and Huminer, D. 1987. Nonenteric infections acquired through contact with water. Riverine Infectious Disease, 9: 54-63.

Rahman, M. and Bakri, D. 2010. A Study on Selected Water Quality Parameters along the River Buriganga, Bangladesh, Iranica Journal of Energy \& Environment, 1(2): 81-92.

Rahman, M. O.; Rabbani, K. A.; Tooheen, R. B. 2011. Slums, Pollution, and Ill Health: The Case of
Dhaka, Bangladesh', Megacities \& Global Health,American Public Health Association.

Ramesh, R. and Anbu, M. 1996. Chemical Methods for Environmental Analysis- water and sediment. Macmillan India Ltd, pp. 15-67.

Ray, M. 1994. Industrial Pollution of irrigation water, affordable water supply and sanitation, 20th WEDC Conference, Colombo, Srilanka.

Rukshana, F.; Haque, M. N.; Mazumder, M. H.; Chowdhury, S. R.; Ahmed, G. U. and Quadir, M. E. 2002. Arsenic investigation of drinking water in some areas of Faridpur district. Tech. J., 9(2): 99107.

Salequzzaman, M.; Tariqul, I. S. M.; Tasnuva, A.; Kashem, M. A. and Mahedi, A. M. M. 2008. Environmental impact of sugar industry - a case study on Kushtia Sugar Mills in Bangladesh: Khulna: Green World Foundation.

Sarker, M. A. K. 2005. Study on the Accumulation And Seasonal Variation of Trace Metals In Water, Sediment and Some Fishes of the Buriganga River. M Sc thesis (1998-1999), Department of Zoology, Dhaka University, Dhaka, Bangladesh. pp. 1-4.

Sattar, M. A. and Rahaman, A. K. M. 2005. Heavy Metal Contaminations in the Environment, Sabdagussa Press, New York.

Singh, K. P.; Malik, A.; Sinha, S.; Singh, V. K. and Murthy, R. C. 2005. 'Estimation of Source of Heavy Metal Contamination in Sediments of Gomti River (India) using Principal Component Analysis', Water, Air, and Soil Pollution, 166: 321-341.

Vega, M. R.; Barrado, E. and Deban, L. 1998. Assessment of seasonal and polluting effects on the quality of river water by exploratory data analysis. Wat. Res., 32(12): 3581-3592.

WHO. 2002. water pollutants: Biological Agents, Dissolved Chemicals, Non-dissolved chemicals, sediments, Heat. WHO CEHA, Amman, Jordan. 